THE INTERACTION BETWEEN THE DEBT RELIEF MEASURES IN THE NATIONAL CREDIT ACT 34 OF 2005 AND ASPECTS OF INSOLVENCY LAW

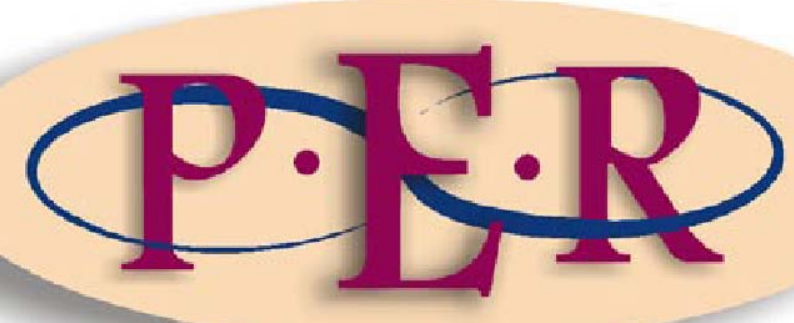

2009 VOLUME 12 No 3 


\section{THE INTERACTION BETWEEN THE DEBT RELIEF MEASURES IN THE NATIONAL CREDIT ACT 34 OF 2005 AND ASPECTS OF INSOLVENCY}

\section{LAW}

\section{C van Heerden ${ }^{*}$ and A Boraine ${ }^{* *}$}

\section{Introduction}

One of the main features of the National Credit Act, ${ }^{1}$ which came into full operation on 1 June $2007,{ }^{2}$ is its objective to afford debt relief to over-burdened consumers. Otto remarks that the NCA is an ambitious, perhaps even idealistic, piece of legislation with pronounced socio-economic aims. ${ }^{3}$ The purpose of the NCA as stated in section 3 thereof is inter alia to promote responsibility in the credit market by encouraging responsible borrowing, avoidance of overindebtedness and fulfilment of financial obligations by consumers, and to discourage reckless credit granting by credit providers and contractual default by consumers. ${ }^{4}$ It aims to address and prevent over-indebtedness of consumers and provides mechanisms for resolving over-indebtedness based on the principle of satisfaction by the consumer of all responsible financial obligations. $^{5}$

Over-indebtedness is addressed by providing for debt review and the restructuring of credit agreement debt. Whilst the consumer is under debt

* B Proc LLB LLM LLD, Associate Professor, Faculty of Law, University of Pretoria.

** B lur LLB LLM LLD, Professor, Faculty of Law, University of Pretoria.

1 Act 34 of 2005 (hereinafter the 'NCA' or the 'Act').

2 S 172(4) of the NCA repeals the Usury Act 73 of 1968, the Credit Agreements Act 75 of 1980 and the Integration of Usury Laws Act 57 of 1996. See further Scholtz et al Guide to the National Credit Act par 2.2.

3 Otto National Credit Act explained; Scholtz et al (n 2) par 2.3.

4 S 3(c)(i) and (ii).

5 S 3(g). The NCA provides for debt restructuring in accordance with s 86(7(c) but does not afford a consumer a discharge, for instance, after a certain period. 
review or subject to a debt restructuring order or agreement, the credit provider is not entitled to exercise or enforce his rights or security under the agreement by means of litigation or any other judicial process. ${ }^{6}$ Provisions relating to individual debt enforcement by means of judgment and repossession are set out in Part C of Chapter 6 of the NCA and it is clear that a credit provider will not be able to proceed with such litigation to enforce his rights or security under a credit agreement against a consumer who is under debt review, or subject to a debt restructuring order or agreement. ${ }^{7}$ In order to promote sensible lending practices, reckless credit granting is met with severe sanctions which include complete or partial setting aside of the consumer's rights and obligations under the agreement, or suspension of the force and effect of the agreement in accordance with section $83(3)(b)(i){ }^{8}$ It is clear that a person who is overburdened with debt, be that credit agreement debt that is regulated by the NCA or other debt, may consider sequestration by means of voluntary surrender as an option to deal with his or her debt situation. One or more of such a debtor's creditors may also consider an application for compulsory sequestration of his or her estate. The question thus inevitably arises what the effect of debt review and debt restructuring, where applicable, is with regard to insolvency law in general and sequestration in particular.

Insolvency law brings about a concursus creditorum that entails a collective debt settlement procedure that, unlike the NCA, does not operate on the principle of extension or restructuring of payment to achieve eventual satisfaction of debts. The role and function of having some credit agreements declared reckless may also affect insolvency proceedings, since a declaration of reckless credit can lead to punitive measures against the creditor that may be of some benefit to the debtor.

$6 \mathrm{~S} 88(3)$.

7 See $\mathrm{s} 130(3)(\mathrm{c})(\mathrm{i}), 130(4)(\mathrm{c})$.

8 S 83(2). 
The purpose of this article is therefore to investigate the impact of the debt relief remedies in the NCA on insolvency law with specific reference to the following questions:

(a) Does the NCA exclude the application of the Insolvency Act $^{9}$ as being in conflict with the principle of satisfaction of all responsible financial obligations by an over-indebted consumer?

(b) If not, what is the effect of section 88(3) of the NCA with regard to the application of the Insolvency Act?

(c) To what extent must a court in insolvency proceedings consider the concepts of over-indebtedness and reckless credit and their related debt relief remedies when considering applications for voluntary surrender or compulsory sequestration in terms of the Insolvency Act?

These questions will be considered against the backdrop of a summary of some of the salient provisions of the NCA.

\section{Over-indebtedness, reckless credit and the debt relief measures in terms of the NCA}

\section{$2.1 \quad$ Over-indebtedness}

Part D of Chapter 4 of the NCA deals with over-indebtedness and reckless credit and the debt relief measures afforded in respect thereof. This Part applies only to natural person consumers and is not available to a consumer who is a juristic person. ${ }^{10}$ Over-indebtedness has a very specific meaning within the context of the NCA as it applies only to credit agreement debt to

9 Act 24 of 1936 (hereafter the 'Insolvency Act').

$10 \mathrm{~S} 78(1)$. 'Juristic person' has an extended definition in terms of the NCA and includes a partnership, association or other body of persons, corporate or unincorporated, or a trust if there are three or more individual trustees or the trustee itself is a juristic person, but does not include a stokvel. 
which the Act applies. ${ }^{11}$ For purposes of the Act, a natural person consumer is over-indebted if the preponderance of available information at the time a determination is made ${ }^{12}$ indicates that the particular consumer is or will be unable to satisfy in a timely manner all of the obligations under all of the credit agreements to which the consumer is a party, having regard to that consumer's:

(a) financial means, prospects and obligations; ${ }^{13}$ and

(b) probable propensity to satisfy in a timely manner all of the obligations under all of the credit agreements to which the consumer is a party, as indicated by the consumer's history of debt repayment. ${ }^{14}$

Over-indebtedness thus relates not only to existing inability to satisfy obligations but it also extends to future or proximate inability; hence the words "or will be unable to satisfy" in section $79(1) .{ }^{15}$

\subsubsection{Debt relief for over-indebtedness}

Over-indebtedness is addressed essentially by providing for debt relief in the form of debt restructuring. Courts are given the power in section 85 of the Act to declare and relieve over-indebtedness. Section 86 provides for an application for debt review by a debt counsellor. Debt review and debt restructuring denote two distinct stages of the debt relief process. The initial stage occurs before the

11 For the scope and application of the NCA see Scholtz et al (n 2) ch 4. See also Stoop 2008 De Jure 352.

12 See Scholtz et al (n 2) par 11.3.2. When a determination is to be made whether a consumer is over-indebted or not, the person making that determination must apply the criteria set out in s 79(1) "as they exist at the time a determination is being made". Such determination is made only at the stage when the issue of over-indebtedness is raised. This implies that a determination of general over-indebtedness is not made retrospective to the time the credit agreement was entered into, but only at the time at which the issue of over-indebtedness is raised.

13 See s 78(3) for an explanation of "financial means, prospects and obligations".

$14 \mathrm{~S} 79(1)(\mathrm{a})$ and (b).

15 Scholtz et al (n 2) par 11.3.2. 
debt counsellor and is referred to as debt review (or debt counselling) ${ }^{16}$ and the second stage comprises of an actual declaration of over-indebtedness and the subsequent restructuring, which is done by the court, alternatively on the filing of a consent order in terms of section 138 of the NCA. Consumers who are over-indebted thus have the option of taking the initiative and applying to a debt counsellor for debt review once they realise they are over-indebted. Where defaulting consumers have not themselves taken the initiative of approaching a debt counsellor, the credit provider may decide to institute court proceedings against them in order to enforce the credit agreement. The credit provider is then obliged prior to enforcement in terms of Part $C$ of Chapter 6 to give them notice in terms of section 129(1)(a) of the Act that they can inter alia approach a debt counsellor. Consumers can also raise the issue of over-indebtedness in court in accordance with section 85 .

Section 85 gives the court the discretion despite any provision of law or agreement to the contrary, in any court proceedings in which a credit agreement is being considered, if it is alleged that the consumer under a credit agreement is over-indebted, to refer the matter directly to a debt counsellor with a request that the latter evaluate the consumer's circumstances and make a recommendation to the court in terms of section 86(7) ${ }^{17}$ Alternatively the court itself may declare that the consumer is over-indebted and make any order contemplated in section 87 to relieve the consumer's over-indebtedness. ${ }^{18}$

In Standard Bank of South Africa Ltd v Hales ${ }^{19}$ the plaintiff successfully foreclosed on a mortgage bond after the defendant (consumer) relied on section 85 of the NCA by raising over-indebtedness as a defence. The court dealt with the discretion of the court to refer a matter to a debt counsellor in terms of section 85 of the NCA. The court firstly ruled that section 85(a)

16 Also referred to as 'debt counselling'. Reg 1 defines debt counselling as "performing the functions contemplated in section 86 of the Act".

$17 \mathrm{~S} 85(\mathrm{a})$. The word 'may' is used.

$18 \mathrm{~S} 85(\mathrm{~b})$. See the discussion in par 2.2.1 below.

192009 (3) SA 315 (D). 
empowers a court to refer a matter to a debt counsellor for a recommendation when (1) the proceedings before the court relate to a credit agreement, and (2) it is alleged during such proceedings that a consumer under the credit agreement is over-indebted. ${ }^{20}$ When these two factors are present the court has a discretion to refer the matter to a debt counsellor to make a recommendation to the court in terms of section 86(7) of the NCA. In order to exercise its discretion the legislature did not, however, list specific factors to be taken into consideration by the court in this regard. According to the court, the purposes of the NCA as stated in section 3 and other relevant sections are merely intended to serve as a backdrop against which the court must exercise its discretion. ${ }^{21}$ After deciding that it is neither the sole nor the chief purpose of the NCA to protect consumers, the court indicated that there must be a balancing act of rights and responsibilities of both consumers and credit providers. ${ }^{22}$ Based on the available facts the court refused to refer the matter to a debt counsellor on the premise that it was not feasible to extend the mortgage bond debt further, or for the consumer to recover financially after a further suspension of instalments. In fact the court indicated that a further extension could even increase the indebtedness in the absence of a financial recovery. ${ }^{23}$ Since there appeared to be little potential for the consumer to successfully reschedule the indebtedness, the court refused to refer the matter to a debt counsellor. In its summary the court stated that when exercising its discretion to refer a matter to a debt counsellor a court may look at the following factors, which are not an exhaustive list: ${ }^{24}$ the circumstances in which the debt was incurred; any attempts made by the debtor to pay of the debt; the financial situation of the parties; the amount of the debt; whether the debtor is employed or has a source of income to pay off the debt; and any other factor relevant to the facts of the particular case before the court.

20 Ibid par 6-7.

21 Ibid par 12, 22 and 26. See also Firstrand Bank Ltd v Olivier 2009 (3) SA 353 par 14 and 23-24 regarding the exercising of the court's discretion in this regard.

22 Ibid par 13.

23 Ibid para 22-23.

24 Ibid par 60. 
It should be noted that only a court can declare a consumer over-indebted and make an order for debt restructuring, as explained hereinafter. A debt counsellor is merely empowered to conduct a debt review to determine if a consumer is over-indebted and if any reckless credit has been extended to such a consumer.

\subsection{Debt Review}

The procedure for debt review is set out in section 86 of the NCA, read together with regulations 24 to 26 . In brief, debt review has commenced when a consumer applies to a debt counsellor ${ }^{25}$ for an evaluation to determine whether the consumer is over-indebted. The debt review process is quite detailed and comprises various stages, namely the consumer's application for debt review, the subsequent duties of the debt counsellor, the obligations of the consumer and credit providers during the debt review process, the debt counsellor's determination of over-indebtedness, and steps that may be taken after such determination. The Act also provides for termination of debt review in certain circumstances. $^{26}$

\subsubsection{Declaration of over-indebtedness and debt restructuring}

The main aim of debt review is to determine whether or not a consumer is overindebted and whether or not reckless credit has been extended to him or her. During a debt review, on the initiative of the consumer or in pursuance of a

25 S 44

$26 \mathrm{~S}$ 86(10) provides that if a consumer is in default under a credit agreement that is being reviewed in terms of $s$, the credit provider in respect of that credit agreement may give notice to terminate the review in the prescribed manner to the consumer, the debt counsellor and the National Credit Regulator. Such notice may be given only after 60 business days after the date on which the consumer applied for the review. However, the irony is that the termination of the debt review does not mean that the consumer forfeits any further opportunity for debt relief. In this regard $s$ 86(11) is quite significant as it provides that if a credit provider who has given notice to terminate a review as contemplated in s 86(10) proceeds to enforce that agreement in terms of Part C of Chapter 6 , the magistrate's court hearing the matter may order that the debt review resume on any conditions the court considers just in the circumstances. 
section 129(1)(a) notice or as a result of a referral by the court in terms of section 85, a debt counsellor may thus make any of the following determinations:

(a) A determination that the consumer is not over-indebted

In this instance the debt counsellor must reject the consumer's application for debt review even if the debt counsellor has concluded that a particular agreement was reckless at the time it was entered into. ${ }^{27}$ However, all hope of debt relief is not lost to the consumer, as section 86(9) provides that if a debt counsellor rejects an application for debt review as indicated in section 86(7), the consumer with the leave of the Magistrate's Court may apply directly to the Magistrate's Court for an order contemplated in section 86(7)(c). Such an order may declare one or more credit agreements to be reckless credit and may restructure one or more of the credit agreements. ${ }^{28}$

(b) A determination that the consumer is not over-indebted yet, but is experiencing or likely to experience problems in future

In such an instance the debt counsellor may recommend that the consumer and the respective credit providers voluntarily consider and agree on a plan of debt re-arrangement. ${ }^{29}$ If a debt counsellor makes a recommendation in terms of section $86(7)(b)$ and the consumer and each credit provider concerned accept that proposal, the debt counsellor must record the proposal in the form of an order. ${ }^{30}$ If it is consented to by the consumer and each credit provider concerned, the order must then be filed as a consent order in terms of section

$27 \mathrm{~S} 86(7)(\mathrm{a})$.

28 For a detailed discussion see Scholtz et al (n 2) par 11.3.3.2(i).

29 S 86(7)(b). As indicated, s 86(5) obliges credit providers to participate in good faith in the review and in any negotiations designed to result in responsible debt arrangement.

30 S 86(8)(a). See also reg 24(9) which provides that any arrangement made by the debt counsellor with credit providers must be reduced to writing and signed by all credit providers mentioned, the debt counsellor and the consumer. 
138. ${ }^{31}$ Should the debt counsellor's proposal not be accepted, the debt counsellor must refer the matter to the Magistrate's Court together with the recommendation. ${ }^{32}$

(c) A determination that the consumer is over-indebted

If, as a result of the debt review assessment conducted by the debt counsellor, he or she reasonably concludes that the consumer is over-indebted, the debt counsellor may issue a proposal recommending that the Magistrate's Court make an order that the consumer's credit agreements be declared to be reckless credit, ${ }^{33}$ and/or ${ }^{34}$ that one or more of the consumer's obligations be rearranged. ${ }^{35}$ Section $86(7)$ (c)(ii) provides that the court may rearrange the consumer's obligations in the following ways:

(i) by extending the period of the agreement and reducing the amount of each payment due accordingly; ${ }^{36}$

(ii) by postponing during a specified period the dates on which payments are due under the agreement; ${ }^{37}$

(iii) by extending the period of the agreement and postponing during a specified period the dates on which payments are due under the agreement; ${ }^{38}$ or

(iv) by re-calculating the consumer's obligations because of contraventions of Part A or B of Chapter 5 or Part A of Chapter $6^{39}$

$31 \mathrm{~S} 86(8)(\mathrm{a})$. S 138(1) provides that if a matter has been (a) resolved through the ombud with jurisdiction, consumer court or alternative dispute resolution agent; or (b) investigated by the National Credit Regulator and the respondent agrees to the proposed terms of an appropriate order, the Tribunal or a court, without hearing any evidence, may confirm that resolution or agreement as a consent order. S 138(2) further provides that, with the consent of a complainant, a consent order confirmed in terms of $s$ 138(1)(b) may include an award of damages to the complainant.

$32 \mathrm{~S} 86(8)(\mathrm{b})$.

33 S 86(7)(c)(i).

34 S 87(6)(c) - either or both.

35 S 87(6)(c)(ii).

36 S 86(7)(c)(ii)(aa).

37 S 86(7)(c)(ii)(bb).

38 S 86(7)(c)(ii)(cc). 
The debt restructuring process poses a number of problems, due mainly to a lack of procedural clarity. The Act imposes no time limitation upon such restructuring with the result that restructuring orders that run over unrealistically long periods of time are sometimes granted by courts. ${ }^{40}$ However, no provision is made for the discharge of debt after a certain period of payment, or repayment of a certain amount of the original debt. It is unclear what a credit provider's remedies are if he or she is of the opinion that the period of restructuring is unreasonably long and not to his benefit. It is submitted that as the procedure currently stands a credit provider will be able to contest debt restructuring only in respect of a consumer who has in fact been declared overindebted by a court on the basis that the consumer has enough money available to make larger payments than is proposed to the court. As the object of debt restructuring is fulfilment of financial obligations without any time limit or the possibility of a discharge being linked thereto, it appears that a credit provider is in dire straits and will have to accept the payments in terms of the proposed restructuring ordered by the court even if it has the effect that a debt takes the whole of the consumer's lifetime to settle. In this regard the practical difficulties experienced with other debt relief measures like the administration order in terms of section 74 of the Magistrates' Courts Act, ${ }^{41}$ are bound to arise within the ambit of debt relief as well. ${ }^{42}$

As long as the consumer pays in terms of the debt restructuring order, the credit provider will not be able to approach a court to review the order since the procedure does not provide for the order to be reviewed after a specified period

39 S 86(7)(c)(ii)(dd). Part A of Chapter 5 deals with unlawful agreements and provisions and Part B of Chapter 5 deals with the disclosure, form and effect of credit agreements. Part A of Chapter 6 deals with collection and repayment practices.

40 An example on file with the authors grants a restructuring period of 832 months in the case of a debt secured by a mortgage bond.

41 Act 32 of 1944.

42 See in general Greig 2000 SALJ 622 and Boraine 2003 De Jure 217. 
of time. ${ }^{43}$ In Standard Bank of South Africa Ltd $v$ Panayiotts ${ }^{44}$ the court ruled that where a High Court refers a matter to a debt-counsellor for a recommendation in terms of section 85 , the same court may deal with the matter in terms of section $86(7)(c)$ of the NCA.

\subsubsection{Effect of debt review or debt restructuring order or agreement}

Section 88 of the NCA sets out the effect of a pending debt review, a debt restructuring order or a debt rearrangement agreement. It provides that a consumer who has filed an application for debt review in terms of section 86(1) or who has alleged in court that he or she is over-indebted must not incur any further charges under a credit facility or enter into any further credit agreement until one of a number of specified events has occurred. ${ }^{45}$ These events are the following: ${ }^{46}$

(a) the debt counsellor rejects the application for debt review and the prescribed time period for direct filing in terms of section 86(9) has expired without the consumer having so applied; ${ }^{47}$

(b) the court has determined that the consumer is not over-indebted or has rejected a debt counsellor's proposal or the consumer's application; ${ }^{48}$ or

(c) the court made an order for re-arrangement of the consumer's obligations or the consumer and his credit providers came to a re-arrangement agreement and the consumer fulfilled all of his obligations under the credit

43 The current procedure does not make these orders automatically reviewable after a specific time period has elapsed, nor does it place any duty on the court to order that a specific debt restructuring order will be subject to review after, for instance, a year since the order was granted.

442009 (3) SA 363 (W) at par 17-19, For an earlier view to the contrary cf Van Heerden 2008 TSAR 840.

$45 \mathrm{~S} 88(1)$.

$46 \mathrm{~S} 88(1)(\mathrm{a})-(\mathrm{c})$.

$47 \mathrm{~S} 88(1)(\mathrm{a})$.

48 S 88(1)(b). 
agreements as re-arranged, unless the consumer fulfilled the obligations by way of a consolidation agreement. ${ }^{49}$

Where a consumer applies for debt review or where debt re-arrangement occurs whether by court or voluntary agreement with his credit providers the consequences for the credit provider are significant. Section 88(3) provides that, subject to section 86(9) and (10), a credit provider who receives notice of court proceedings contemplated in sections 83 or 85 or notice in terms of section 86(4)(b)(i) may not exercise or enforce by litigation or other judicial process any right or security under that credit agreement until: ${ }^{50}$

(a) the consumer is in default under the credit agreement; ${ }^{51}$ and

(b) one of the following has occurred:

(i) an event contemplated in section 88(1)(a) through to (c), ${ }^{52}$ or

(ii) the consumer defaults on any obligation in terms of a rearrangement agreed between the consumer and credit providers, or ordered by a court or the Tribunal. ${ }^{53}$

\section{$2.3 \quad$ Reckless credit}

As indicated, the provisions of the NCA relating to reckless credit apply only to natural person consumers. Prior to entering into a credit agreement, a credit provider is obliged by the NCA to conduct a credit assessment to establish if a consumer understands his risks, costs, rights and obligations under the

$49 \mathrm{~S} 88(1)(\mathrm{c}) . \mathrm{S} 88(2)$ provides that if a consumer fulfils obligations by way of a consolidation agreement as contemplated in $\mathrm{s} 88(1)$ (c) or $\mathrm{s} 88(2)$, the effect of $s$ 88(1) continues until the consumer fulfils all of the obligations under the consolidation agreement, unless the consumer again fulfils the obligations by way of a consolidation agreement.

$50 \mathrm{~S} 88(3)$.

51 S 88(3)(a).

$52 \mathrm{~S} 88(3)(\mathrm{b})(\mathrm{i})$.

53 S 88(3)(b)(ii). 
agreement and can actually afford the credit. ${ }^{54}$ In terms of section 80 , a credit agreement will be reckless if, at the time that the agreement was made, ${ }^{55}$ or at the time when the amount approved in terms of the agreement is increased, other than an increase in terms of section 119(4):

(a) the credit provider failed to conduct an assessment as required by section 81(2), irrespective of what the outcome of such an assessment might have been at the time, ${ }^{56}$ or

(b) the credit provider, having conducted an assessment as required by section 81(2), entered into the credit agreement with the consumer, despite the fact that the preponderance of information available to the credit provider indicated that:

(i) the consumer did not generally understand or appreciate his or her risks, costs or obligations under the proposed credit agreement, ${ }^{57}$ or

(ii) entering into that agreement would make the consumer over-indebted. ${ }^{58}$

Section 83 gives a court the discretion, despite any provision of law or agreement to the contrary, in any court proceedings in which a credit agreement is being considered, to declare that a credit agreement is reckless. Section 83 appears to differ from section 85 in the sense that a court may suo motu declare a credit agreement reckless in terms of section 83 whereas a court can declare a consumer over-indebted in terms of section 85 only if it is alleged that the consumer is over-indebted. If a court declares that a credit agreement is reckless in terms of sections $80(1)(a)$ or $80(1)(b)(i)$, it may make an order setting aside all or part of the consumer's rights and obligations under

$54 \mathrm{~S} 81$.

55 See Scholtz et al (n 2) par 11.4.4. The crucial time for determining whether or not credit was recklessly extended is the time of entry into the agreement, not the time at which the issue of reckless credit is raised.

56 S 80(1)(a).

57 S 80(1)(b)(i).

58 S 80(1)(b)lii). 
that agreement, as the court determines to be just and reasonable in the circumstances. ${ }^{59}$ Alternatively, it may make an order suspending ${ }^{60}$ the force and effect of that specific credit agreement in accordance with section $83(3)(b)(i)$.

During the period that the force and effect of a credit agreement is suspended in terms of the NCA, section 84(1) provides that the consumer is not required to make any payment required under the agreement; no interest, fee or other charge under the agreement may be charged to the consumer; and the credit provider's rights under the agreement, or under any law in respect of that agreement, are unenforceable, despite any law to the contrary. In accordance with section 84(2), after a suspension of the force and effect of a credit agreement all of the respective rights and obligations of the credit provider and the consumer under that agreement are revived, and are fully enforceable except to the extent that a court may order otherwise, and no amount may be charged to the consumer by the credit provider with respect to any interest, fee or other change that could not be charged during the suspension in terms of section 84(1)(b). If, however, a court declares that a credit agreement is reckless in terms of section 80(1)(b)(ii), it must further consider whether or not the consumer is over-indebted at the time of the court proceedings. ${ }^{61}$ If the court then concludes that the consumer is over-indebted it may make an order suspending the force and effect of that credit agreement until a date determined by the court when making the order of suspension. In addition it may then also restructure the consumer's obligations under any other credit agreements in accordance with section $87 .^{62}$

The significance of a determination of reckless credit by a court is that it has the effect that a consumer can in some instances obtain significant debt relief, for

59 S 83(2)(a).

60 See $s$ 84(1) and (2) as discussed below.

61 S 83(3)(a).

62 See discussion above. 
instance by the setting aside of the agreement, or at the very least the suspension of the agreement and the restructuring of his other credit agreement debt. The fact that a court can also suo motu raise the issue of reckless credit in proceedings in which a credit agreement is being considered further has the effect that a consumer may, at the initiative of the court, eventually be granted debt relief in the form of setting aside of the relevant credit agreement, for instance, or in the form of the suspension of that agreement and the restructuring of his other credit agreement debt.

\section{Does the NCA exclude the application of the Insolvency Act regarding credit agreements in general?}

Section 2(1) of the NCA provides that the Act must be interpreted in a manner that gives effect to the purposes set out in section 3. However, section 2(7) provides that, except as specifically set out in or necessarily implied by the Act, its provisions are not to be construed as limiting, amending, repealing or otherwise altering any provision of any other Act.

In none of the sections in the NCA is there any specific mention of the Insolvency Act. Schedule I to the Act sets out the rules regarding conflicting legislation. If the argument is that compulsory sequestration of a consumer in accordance with the provisions of the Insolvency Act is in direct conflict with the provisions of the NCA relating to debt review and debt restructuring which is focused on satisfaction of all responsible financial obligations, one would at least expect either a direct provision dealing with the issue, or at the very least that a conflict resolution rule be provided for in Schedule I to the Act. However, no mention of the Insolvency Act is made in Schedule I.

It is submitted that if the legislature intended the provisions of the NCA to override the conflicting provisions of the Insolvency Act, it would have expressly stated so in Schedule I. The only reasonable inference is thus that it was not 
the legislature's intention in the event of conflict between the Insolvency Act and the NCA that the latter should prevail as a rule. It is clear from Schedule 2 that the legislature was, however, aware of and did consider the Insolvency Act. It is further submitted that Schedule 2 of the NCA has a significant bearing on the intention of the legislature with regard to the application of the Insolvency Act. In the very first column of Schedule 2 it is provided that section 84 of the Insolvency Act should be amended by:

(a) the substitution for the heading of the following heading:

"Special provisions in case of goods delivered to a debtor in terms of an instalment agreement"; and

(b) the substitution for the opening clause of subsection (1) of the following words: "If any property was delivered to a person (hereinafter referred to as the debtor) under a transaction that is an instalment agreement contemplated in paragraph (a), (b) and (c)(i) of the definition of instalment agreement set out in section 1 , of the National Credit Act 2005".

Section 84 of the Insolvency Act affords a credit provider who has sold property to a consumer in terms of an instalment agreement in respect of which ownership is reserved until payment of all amounts due, on sequestration of the consumer, a hypothec over the property which secures his claim for the balance outstanding under the agreement. ${ }^{63}$ Such a creditor provider thus ranks as a secured creditor in the insolvent estate of the consumer. It appears illogical that a legislature which intends to oust the working of insolvency law with regard to a consumer who is under debt review or subject to a debt restructuring order or agreement fails to provide expressly that the insolvency law will not apply, and furthermore proceeds to amend the provision in the Insolvency Act relating to the credit provider's hypothec with regard to an

63 Nagel et al Commercial Law par 34.66. See also Sharrock et al Hockly's Insolvency Law (2007) par 7.2.8. 
instalment agreement. One can only reasonably conclude that this indicates that the legislature did not intend to oust the application of insolvency law.

In the absence of an express provision ousting the application of the Insolvency Act, it might thus be argued that the amendment of section 84 of the Insolvency Act militates against a finding that the legislature intended to oust the application of the Insolvency Act by necessary implication. It is further submitted that the application of the Insolvency Act is not excluded by necessary implication as any construction in terms of which it is concluded that a pending debt review or a debt restructuring order, or agreement, is a bar to sequestration can lead to absurdity. Such a conclusion may even result in the unequal treatment of credit providers, many of whom, such as in the instance of instalment agreements or mortgage bonds, would have been secured creditors on insolvency. It further gives rise to unequal treatment of debtors, allowing some an undeserved payment holiday which might span over years whereas others, whilst having to live with the impediments of insolvency, may qualify for a debt discharge on rehabilitation, which can in certain instances occur within a relatively short period of time. ${ }^{64}$

It is foreseeable that there will be consumers who have debt that falls within the ambit of the NCA as well as debt to which the NCA does not apply. The prohibition against exercising or enforcing rights or security under a credit agreement which is subject to debt review applies only to credit providers who are party to a credit agreement that falls within the scope of the NCA and is eligible for the debt review procedure. This does not bar a creditor who has a claim that does not constitute a credit agreement covered by the NCA, for example a delictual claim, from applying for the sequestration of the debtor. To prevent such a creditor from sequestrating a consumer merely because the consumer is under debt review with regard to a credit agreement to which the aforesaid creditor is not a party would amount to an unjustified deprivation of 
his right to sequestrate an insolvent debtor to the advantage of the group of creditors as a whole.

Further, it would have the effect that a debtor who is under administration in terms of section 74 of the Magistrates' Courts Act, which is also a remedy that provides for debt restructuring, may be sequestrated ${ }^{65}$ but not one whose credit agreement debt is being restructured in accordance with the NCA. The irony is that administration applications have a monetary cap of R50 000, which means that the chances of succeeding with the sequestration of a person under administration will be slim as there may not be advantage to creditors.

\section{Effect of section 88(3) of the NCA on application of Insolvency Act}

As indicated, the provisions of section 88(3) apply only to credit providers who want to exercise and enforce their rights under a credit agreement ${ }^{66}$ by means of litigation or a judicial process, and not to any other creditors. Once the question as to whether or not the NCA excludes the application of the Insolvency Act in general is answered in the negative, it needs to be ascertained if section 88(3) of the NCA specifically prevents a credit provider from applying for the sequestration of his or her consumer-debtor who is under debt review, or subject to a debt restructuring order, or a debt restructuring agreement that was made a consent order in terms of section 138 of the NCA.

From the perspective of the credit provider, an interpretation of the words "may not exercise or enforce by litigation or other judicial process any right or security under that credit agreement" as contained in section 88(3) is of utmost importance. It is submitted that the exercising of his or her rights under a credit agreement refers to the credit providers' right to obtain payment from the

65 S 74R of the Magistrates' Courts Act 32 of 1944.

66 To which the NCA applies. 
consumer. ${ }^{67}$ However, what exactly is meant by the word 'enforce' in this context is not defined and is thus not clear in all respects. 'Enforce' is a term that has been introduced by the Act. Since the Act does not define the term, uncertainty exists as to its exact meaning. The ordinary meaning in legal parlance would be enforcement of payment or of another obligation, but in the context of the Act, Otto submits that it may well include enforcement in the sense of the credit provider's using any of his remedies. ${ }^{68}$ In other words, enforcement of the agreement means the exercise of his or her remedies by a credit provider. ${ }^{69}$ This would for instance include the implementation of a lex commissoria. $^{70}$

'Litigation' usually refers to legal proceedings instituted in a court of law. It is submitted that "other judicial process" refers to judicial proceedings that do not formally occur in a court, such as arbitration. It may consequently be asked if sequestration proceedings amount to the exercising or enforcing of a right or security under a credit agreement by litigation or other judicial process for purposes of section 88(3) of the NCA. Although it must be conceded that sequestration may amount to some kind of enforcement, the view that compulsory sequestration merely amounts to enforcement by litigation or judicial process of a right or security under a credit agreement is simplistic and untenable. It has been held that an application for sequestration is not a process whereby the creditor claims payment of a debt. ${ }^{71}$ Even though this is a debatable issue and though sequestration proceedings also be viewed as a collective debt collection device too, it should be borne in mind that sequestration may be used to achieve more objectives within the ambit of debt relationships than merely the collection of debt. ${ }^{72}$ For instance, sequestration

67 Otto National Credit Act explained 87.

68 Ibid.

69 Ibid.

70 Ibid.

71 WP Kooperatief Bpk v Louw 1995 (4) SA 4 (O).

72 In Samsudin $v$ De Villiers Berrange [2006] SCA 79 (RSA) at par 19 the SCA approved of an earlier dictum in Ex Parte B Z Stegmann 1902 TS 40, 47 that '[a]n order of sequestration is not an ordinary judgment of the court, but is rather a species of arrest or $40 / 161$ 
affects not only the debtor's assets but also affects the debtor personally, restricting his capacity and freedom to enter into contracts, to follow a chosen vocation, to litigate and to hold office. ${ }^{73}$ There may also be other compelling reasons for obtaining a sequestration order against a particular consumerdebtor, as in the instance where other creditors are in the process of depleting his or her assets by means of judgment, attachment and sale in execution that may be to the prejudice of the abovementioned credit provider, and utilising the procedures provided for by insolvency law to carry out interrogations and to trace assets. It is thus submitted that 'enforce' for purposes of section 88(3) should be interpreted restrictively with reference to Part C of Chapter 6 of the Act, which bears the heading "debt enforcement by judgment or repossession". As such it will therefore not include insolvency proceedings. Nevertheless, it is abundantly clear from section 88(3) that such a credit provider may enforce his rights when the consumer-debtor defaults on his rearrangement and whatever the circumstances, like any other creditor-applicant, he will still have to meet all of the requirements set for compulsory sequestration before a court will consider the granting of a sequestration order.

\section{$5 \quad$ Insolvency Law}

\subsection{Introduction}

A debtor ${ }^{74}$ may be either commercially or factually insolvent. Commercial insolvency entails that a debtor is unable to pay his debts. ${ }^{75}$ The legal test for insolvency for the purposes of sequestration proceedings is usually the balance

execution, affecting not only the rights of the two litigants but also third parties, and involves the distribution of the insolvent's property to various creditors, while restricting those creditors' ordinary remedies and imposing disabilities on the insolvent.' It is thus also clear from this passage that we are not dealing with ordinary debt enforcement in a case of sequestration.

73 Sharrock et al (n 63) 5.

74 For the purposes of this discussion the term 'debtor' is limited to natural persons who qualify as consumers for the purposes of the NCA, although the term 'debtor' as defined in $\mathrm{s} 2$ of the Insolvency Act includes some other types of debtors as well.

75 Sharrock et al (n 63) par 1.1. 
sheet test, namely, whether or not the debtor's liabilities, fairly estimated, exceed his assets, fairly valued. ${ }^{76}$ In the case of voluntary surrender the debtor must inter alia prove that his or her liabilities exceed the value of his or her assets. In the case of compulsory sequestration a creditor may have good reason for believing that the debtor is insolvent, but he or she will usually not be in a position to prove that the debtor's liabilities exceed his or her assets. ${ }^{77}$ Consequently the legislature has designated certain acts or omissions by a debtor as acts of insolvency and if the creditor can establish that the debtor has committed one or more of these 'acts' he or she may seek an order sequestrating the debtor's estate without having to prove that the debtor is actually insolvent. ${ }^{78}$ It thus follows that a debtor's estate may in some cases be sequestrated even though he or she is technically solvent. ${ }^{79}$

Once an order of sequestration is granted, a concursus creditorum is established and the interest of the creditors as a group enjoys preference over the interests of individual creditors. ${ }^{80}$ This principle was explained as follows by Innes CJ in Walker $v$ Syfret: ${ }^{81}$

The object of the [Insolvency Act] is to ensure a due distribution of assets among creditors in the order of their preference... The sequestration order crystallizes the insolvent's position; the hand of the law is laid upon the estate, and at once the rights of the general body of creditors have to be taken into consideration. No transaction can thereafter be entered into with regard to estate matters by a single creditor to the prejudice of the general body. 325.

77 Sharrock et al (n 63) par 3.1.2.

78 Ibid. See De Villiers v Maursen Properties (Pty) Ltd 1983 (4) SA 670 (T) 676. Significantly, it has been held that a debtor who applies for an administration order in terms of $\mathrm{s} 74$ of the Magistrates' Courts Act 32 of 1944 is obliged to state that he cannot pay any of his debts, and hence usually commits an act of insolvency in terms of s 8(g) of the Insolvency Act in the process. Volkskas Bank ('n Divisie van Absa Bank Beperk) v Pietersen 1993 (1) SA 312 (C) 316. It is submitted that a notice to a creditor that a consumer-debtor is bound to go for debt review may also amount to an act of insolvency, although the mere commission of an act of insolvency is not in itself sufficient to warrant the granting of a compulsory sequestration order.

79 Ibid. See DP Du Plessis Prokureurs v Van Aarde 1999 (4) SA 1333 (T) 1335.

80 Richter v Riverride Estates (Pty) Ltd 1946 OPD 209, 233.

81 Walker v Syfret 1911 AD 141, 166. 
The main objective of a sequestration order is to secure the orderly and equitable distribution of a debtor's assets where they are insufficient to meet the claims of all his creditors. ${ }^{82}$ The legal machinery that comes into operation on sequestration is designed to ensure that whatever assets the debtor has are liquidated and distributed among all of his creditors in accordance with a predetermined (and fair) order of preference. ${ }^{83}$ It should, however, be noted that despite the impediments inherent in being declared insolvent, insolvency has the advantage of eventually affording a consumer debt relief in the form of a discharge. ${ }^{84}$

The Insolvency Act provides for two forms of sequestration, namely voluntary surrender (where the debtor surrenders his estate on his own initiative) and compulsory sequestration (where a creditor applies to have the debtor sequestrated).

\subsection{Voluntary surrender}

The court has a discretion to accept the voluntary surrender of a debtor's estate and grant a sequestration order if it is satisfied that:

(a) the debtor is insolvent;

(b) there is sufficient free residue to defray the costs of sequestration;

(c) it will be to the advantage of creditors; and

(d) the formalities in section 4 of the Insolvency Act have been complied with.

The onus of proving that these requirements have been met rests upon the debtor.

82 Sharrock et al (n 63) par 1.2.

83 Ibid.

84 See s 129(b) of the Insolvency Act. 


\subsection{Compulsory sequestration}

The court has a discretion to grant an application for the sequestration of a debtor's estate if it is satisfied that:

(a) the applicant is a creditor (or his agent) who has a liquidated claim against the debtor for not less than R100 or two or more creditors (or their agents) who have liquidated claims against the debtor amounting, in aggregate, to not less than R200; ${ }^{85}$

(b) the debtor has committed an act of insolvency or is insolvent; 86

(c) there is reason to believe that it will be to the advantage of creditors of the debtor if his estate is sequestrated; ${ }^{87}$ and

(d) prescribed formalities ${ }^{88}$ have been complied with.

The onus of satisfying the court on these matters rests throughout on the sequestrating creditor and there is no onus on the debtor to disprove any elements. $^{89}$

\subsection{The court's discretion in insolvency applications and the advantage of creditor's requirement}

Even if the court is satisfied that the aforesaid requirements have been established on a balance of probabilities, it is not bound to grant a final order for sequestration. Each case must be decided on its own facts and in each case the court has an overriding discretion that must be exercised judicially and upon a consideration of all the relevant circumstances. ${ }^{90}$ It is submitted that each debt situation is unique and that the courts should follow a common sense

$85 \mathrm{~S} 9(1)$ of the Insolvency Act.

86 See the test for insolvency as stated in the Volkskas case above.

$87 \mathrm{~S}$ 12(1) of the Insolvency Act.

$88 \mathrm{~S} 9$ of the Insolvency Act.

89 Braithwaite v Gilbert 1984 (4) SA 717 (W) 718.

90 Julie Whyte Dresses (Pty) Ltd v Whitehead 1970 (3) SA 218 (D). 
approach to decide if sequestration will be the best solution to a particular debt situation in a specific instance.

The advantage of the creditors plays a pivotal role in the exercise of the court's discretion. It is often on this basis that a court will decline to grant an order for voluntary surrender or compulsory sequestration even though all of the other requirements for it may have been satisfied. It should also be noted that the advantage requirement is more stringent in the case of an application for voluntary surrender than in the case of compulsory sequestration, where it is necessary merely to allege that reason exists to believe that it would be to the advantage of his creditors if the debtor's estate is sequestrated. ${ }^{91}$ In determining such an advantage, the question is if a "substantial portion" of the creditors, ${ }^{92}$ determined according to the value of their claims, will derive advantage from sequestration. ${ }^{93}$ In order to be to the advantage of creditors, sequestration must "yield at the least, a not negligible dividend". ${ }^{94}$ If after the costs of sequestration have been met there is no payment to creditors, or only a negligible one, there is no advantage. ${ }^{95}$

It should be noted that the test for advantage to creditors is relaxed by the requirement that the court must merely be satisfied that there is reason to believe that sequestration will be to the advantage of creditors. ${ }^{96}$ However, it is submitted that proving advantage to creditors is not restricted to calculating a not negligible dividend based on the estimated proceeds of a sale of assets in the debtor's possession at the time when a sequestration application is

$91 \mathrm{~S} 10(\mathrm{c})$ of the Insolvency Act.

92 Sharrock et al ( $n$ 63) par 3.1.3 "Creditors means all, or at least the general body of creditors".

93 Ibid. Trust Wholesalers and Woollens (Pty) Ltd v Mackan 1954 (2) SA 109 (N); Fesi v ABSA Bank Ltd 2000 (1) SA 499 (C).

94 Trust Wholesalers and Woollens (Pty) Ltd v Mackan 1954 (2) SA 109 (N) 111.

95 Ibid. London Estates (Pty) Ltd v Nair 1957 (3) SA 591 (D); Ex parte Steenkamp and related cases 1996 (3) SA $822(\mathrm{~W})$.

96 See Meskin v Friedman 1948 (2) SA 555 (W) 558 where Roper J stated: "The facts put before the court must satisfy it that there is a reasonable prospect - not necessarily a likelihood, but a prospect which is not too remote - that some pecuniary benefit will result to creditors". 
contemplated. It should also be borne in mind that there might in certain instances be a reasonable prospect that the trustee, by invoking aspects of the machinery of the Insolvency Act such as the setting aside of impeachable transactions provided for in sections 26 to 30 after an investigation and inquiry, will unearth or recover assets that will yield a pecuniary benefit for creditors. ${ }^{97}$ In the case of compulsory sequestration the situation is sometimes that some creditors have obtained judgment and even writs of execution against some of the assets of the debtor. This might jeopardise the position of other creditors who are not yet in a position to enforce their claims against the debtor. Sometimes such a creditor will indicate in an application for compulsory sequestration that it would be to the advantage of the creditors if a sequestration order is granted since it will amount to a fair distribution of the proceeds of the available assets amongst the creditors.

Clearly, strong resistance against an application for sequestration by creditors should also direct the court in exercising its discretion.

\section{The role of over-indebtedness and reckless credit in insolvency proceedings}

\subsection{Ex parte Ford ${ }^{98}$}

In the recent decision of the Western Cape High Court in Ex parte Ford three applications for voluntary surrender served before the unopposed motion court. It appeared that a major portion of each applicant's liabilities consisted of credit agreement debt to which the NCA applied. ${ }^{99}$ The court found this debt to be strikingly disproportionate in relation to the relatively modest income of each of

97 BP Southern Africa (Pty) Ltd v Furstenburg 1966 (1) SA 717 (O) 720; Walker v Walker [1998] 2 All SA 382 (W) 387; Dunlop Tyres (Pty) v Brewitt 1999 (2) SA 580 (W) 583; Lynn \& Main Inc v Naidoo 2006 (1) SA 59 (N) 68-69; Commissioner, South African Revenue Services v Hawker Air Services (Pty) Ltd; Commissioner, South African Revenue Services $\checkmark$ Hawker Aviation Partnership 2006 (4) SA 292 (SCA) 306.

982009 (3) SA 376 (WCC); also reported in [2009] JOL 23412 (WCC).

99 Ibid par 2. 
the applicants. ${ }^{100}$ In each of the applications it was averred that the applicants had "become insolvent by misfortune and due to circumstances beyond their control, without fraud or dishonesty on their part". ${ }^{101}$ The court consequently indicated that grounds for cogent suspicion of at least some degree of reckless credit extension presented themselves strongly on the disclosed facts in each of the applications. ${ }^{102}$ It indicated that one of the objects of the NCA is to discourage reckless credit and referred to the provisions dealing with the same. ${ }^{103}$ The court then referred to its powers in terms of section 85 of the NCA and pointed out that an evaluation by a debt counsellor could lead to one or more of the consumers' credit agreements being declared reckless credit, resulting in the setting aside of the agreements or suspension of the force and effect thereof. ${ }^{104}$

In view of the aforementioned the court deemed it fit to call upon counsel for the applicants to present argument as to why the over-indebtedness of the applicants should not more appropriately be addressed by using the mechanisms of the NCA "instead of the blunter instrument afforded in terms of the voluntary surrender remedy under the Insolvency Act". ${ }^{105}$ The court indicated that in its opinion section 85 is cast in very wide terms as is evidenced by the words "in any court proceedings". ${ }^{106}$ Thus the limitation of section 85 to

100 Ibid par 3.

101 Ibid.

$102 \mathrm{Ibid}$. The allegation of absence of fraud by the consumer caused the court to assume that in applying for the credit which became the unaffordable burden that drove the applicants to seek the surrender of their estates the credit grantors involved were fully informed of the apparent limits of the applicant's inability to service the debt, or could easily have ascertained the position had they made reasonable enquiries before granting the loan or credit facilities in question.

103 Ibid par 4-7.

104 Ibid par 9.

105 Ibid par 10.

106 Ibid par 12. See also par 11, where counsel for the applicant pointed out that the legislature had been pertinently cognisant of the Insolvency Act when it enacted the NCA, as is apparent from the amendment of s 84 of the Insolvency Act by Schedule 2 of the NCA. Counsel stressed this connection, that the legislature had not seen fit to make any changes to the provisions of the Insolvency Act concerning voluntary surrender. He submitted that s 85 of the NCA was in any event not applicable in proceedings for voluntary surrender under the Insolvency Act, relying mainly on the argument that there were no credit agreements before the court in the current matter. In this regard he thus $47 / 161$ 
proceedings in which a credit agreement is being considered does not imply that the proceedings in question are restricted only to those in which the enforcement of a credit agreement is in issue. ${ }^{107}$ The court pointed out that in terms of the Insolvency Act "a court has to be fully informed of the applicant's proprietary situation ${ }^{108}$ and that an applicant for voluntary surrender must also satisfy the court that the surrender of his estate will be to the advantage of creditors". ${ }^{109}$ It remarked that these considerations, in a matter like any of the three applications before the court, where over-indebtedness is almost exclusively related to debt arising from credit agreements, require the court to take the existence and effect of those agreements into account. ${ }^{110}$ It held that the word 'consider' referred to in section 85 has a broad connotation: in context it denotes that the court proceedings contemplated by the provision must be proceedings in which a credit agreement is taken into account as a relevant matter. ${ }^{111}$ The court remarked that the fact that the NCA leaves the provisions of the Insolvency Act regarding voluntary surrender generally unaffected acknowledges that insolvency can arise in a great variety of circumstances, many of them quite unrelated to over-indebtedness as defined in the NCA. ${ }^{112}$ Therefore it was of the opinion that insolvents whose misfortune arises out of credit agreement transactions would be well advised for the reasons indicated hereinafter to take into account the policy and objects of the NCA and also the special remedies provided by it before opting to apply for the surrender of their estates under the Insolvency Act rather than availing them of the provisions under the NCA. ${ }^{113}$ The court pointed out that in all three applications the applicants filed supplementary affidavits in which they confirmed having been made aware of the court's desire to hear argument on the application of section

argued that s 85 applies only to instances where the consumer resists a credit grantor's claim for performance in terms of a credit agreement on grounds of over-indebtedness. 107 lbid. However, the court did not agree with these arguments.

108 Ibid par 13 with reference to Bertelsmann et al Mars par 3.15.

109 Ibid.

110 Ibid.

111 Ibid.

112 Ibid par 14

113 Ibid. 
85 of the NCA in the context of the apparent character of their overindebtedness. ${ }^{114}$ Each of them testified that they had indeed considered debt counselling but set out in detail how financially impracticable an arrangement of debt repayment would be. ${ }^{115}$

However, the court was dissatisfied as there was no indication on the evidence in any of the three applications that consideration was given in the context of debt counselling to anything beyond an administered debt collection. ${ }^{116}$ In particular there was no indication that the debt counsellors engaged by the applicants gave any consideration to obtaining declarations of reckless credit. ${ }^{117}$ Despite advocating its powers in terms of section 85 , the court still held that, in view of the applicants' resistance to assistance in terms of section 85 of the NCA, it was not going to refer their credit agreements for investigation and report by a debt counsellor ${ }^{118}$ and declared that it was nevertheless open to the applicants to take the necessary steps in this regard on their own initiative. In addition, the court indicated that it was not prepared to exercise its discretion in favour of granting the applications for voluntary surrender due to the applicants' failure to properly explain why their credit agreement debt was not amenable to administration under the NCA to their own benefit as well as to that of their credit-granting creditors who acted responsibly, as distinct from recklessly, in extending credit. ${ }^{119}$ The court considered it as its duty, in the exercise of its discretion in cases like the current, to have proper regard to giving due effect to the public policy reflected in the NCA, which gives preference to the rights of responsible credit grantors over reckless credit

114 Ibid par 15.

$115 \mathrm{lbid}$. In this regard, each of them sets out in tabulated form how the application of their disposable income over the next seven years to service their current debt would still leave them heavily indebted at the end of the period. It is not clear why the court did not find this information helpful.

116 Ibid par 16.

117 Ibid.

118 Ibid par 17.

119 Ibid. 
grantors, and supports full satisfaction, as far as possible, by consumers of all financial obligations. ${ }^{120}$

In closing, the court indicated that the argument that in essence it is for the applicants to choose the form of relief that suits their convenience by mechanically and superficially satisfying the relevant statutory requirements under the Insolvency Act is misdirected, especially where the grant of a selected remedy is discretionary, ${ }^{121}$ and emphasised that the primary object of voluntary surrenders is not the relief of harassed debtors. ${ }^{122}$ The court indicated that there is moreover a consonance between the objects of the relevant provisions of the NCA and the Insolvency Act, that is, "not to deprive creditors of their claims but merely to regulate the manner and extent of their payment". ${ }^{123}$ However, on the incomplete facts disclosed in the current applications the court held that it was left with the impression that the machinery of the NCA is the more appropriate mechanism to be used and consequently refused the applications. ${ }^{124}$

\subsection{Implications for insolvency proceedings and debt relief in general}

Whether or not other divisions of the High Court are going to follow the decision in Ex parte Ford remains to be seen. However, if the said decision can be taken as an indication of the manner in which insolvency proceedings where the consumer has credit agreement debt will be treated in future, it is clear that over-indebtedness and reckless credit may have particular significance with regard to the ability of the applicant to opt for either voluntary surrender or compulsory sequestration to satisfy the court that sequestration is the option most preferable in terms of advantage to creditors where the debt consists largely of credit agreements regulated in terms of the NCA.

120 Ibid par 20.

121 Ibid par 19 with reference to Ex parte Hayes 1970 (4) SA (NC) 96C.

122 Ibid par 21 with reference to Ex parte Pillay; Mayet v Pillay 1955 (2) SA 309 (N) 311E.

$123 \mathrm{Ibid}$ with reference to Nel $v$ Body Corporate of the Seaways Building 1996 (1) SA 131 (SCA) 138E.

124 Ibid par 21-22. 
As an allegation of over-indebtedness is always an inherent issue in insolvency proceedings, an insolvency court would in principle be entitled to invoke the provisions of section 85 of the NCA in cases where the consumer has credit agreement debt, on the basis that section 85 applies to any proceedings in which a credit agreement is being considered. The court is not obliged to do so but has a discretion, as is indicated by the use of the word 'may' in section 85 .

Where the credit agreement debt appears to be disproportionate to the consumer's income, thereby giving rise to a suspicion of reckless credit granting, an insolvency court may invoke its discretion in terms of section 85 to refer the matter for debt review, with the instruction that the possibility of having certain credit agreements declared reckless credit be investigated. If Ford stands, debt counsellors may be well advised to make it clear during debt review that they have not only considered the over-indebtedness of the consumer, but also if any of his credit agreements appear to be reckless, failing which a matter which had served before a debt counsellor for debt review might be referred back for further investigation, thus wasting costs and time for the already overburdened consumer.

It is submitted that insolvency courts will probably choose to invoke the provisions of section 85 of the NCA within the broader context of their discretion to grant or refuse sequestration based on the question of advantage to creditors. The NCA has clearly created debt relief remedies which may have the effect that a consumer whose financial misfortune was brought about by credit agreement debt might escape his debt trap and impending insolvency if afforded an opportunity to pay off his debt over an extended period of time. However, it is shortsighted to take the hard and fast view that full satisfaction of debts as envisaged by debt restructuring in terms of section 86(7)(c) will always be the preferable option in terms of advantage to creditors. Advantage to creditors is about more than just a monetary dividend and is essentially a de facto test that has to be determined with reference to the peculiar 
circumstances of each case. As such a court may find that in particular circumstances creditors may be better served by insolvency proceedings that allow them a payment of a substantial portion of debt owing to them more quickly than by a debt restructuring that might yield a slightly better payment but which spans over the lifetime of the consumer (and which, unlike insolvency, does not allow for an eventual debt discharge). It might be that a creditor needs to collect money owed by the consumer to pay his own creditors in order to ward off sequestration of his estate.

It is further submitted that intervention by creditors in insolvency proceedings could also be indicative of the presence or absence of advantage to creditors, and of whether or not the debt relief remedies afforded by the NCA should be preferred above sequestration. A creditor may for instance decide to intervene in voluntary surrender proceedings if he is of the opinion that a consumer who has not yet been for debt review must do so in order to determine the advantages of debt restructuring, or of having credit agreements declared reckless. Where the consumer is under a debt restructuring order but wishes to apply for voluntary surrender, an order to ensure that his debt is paid within a reasonable time enabling him to qualify for a debt discharge and a fresh start, creditors might intervene if they are of the opinion that their interests (their advantage) would be better served by maintaining debt restructuring payments under the NCA.

In compulsory sequestration proceedings a creditor would also be able to intervene and argue that a consumer with credit agreement debt who has not yet been for debt review before the sequestration application was brought should be referred for debt review so that the court can be fully appraised of the advantages of having his credit agreement debt restructured and/or declared reckless, in order to make an informed decision when considering the issue of advantage to creditors in the exercise of its discretion whether to grant the sequestration order or not. A creditor can also intervene in compulsory sequestration proceedings in respect of a consumer who is already subject to a 
debt restructuring order on the basis that maintaining payments in terms of the restructuring order would serve the advantage of creditors better than sequestration.

Although the Ford-case is correct in that courts do have a discretion to grant sequestration orders or not, especially by considering the advantage-forcreditors requirement, the judgement is also an indication that some judges still remain extremely pro-creditor orientated and that the NCA has to some extent entrenched this position. ${ }^{125}$ This must be seen against the backdrop of international trends and guidelines regarding debt relief measures that propose the availability of a discharge for debtors even outside the strict confines of insolvency law. ${ }^{126}$ Such a discharge may either follow a proper bankruptcy proceeding like sequestration in our legal system, where the debtor loses his estate assets (excluding exempt and excluded assets), or an alternative debt relief measure outside insolvency law that provides for the rescheduling of the repayment period. In the latter instance the repayment period is usually subject to a time-limitation in order to prevent an overburdened debtor from remaining in debt for life - debt that will in many instances not be repaid in full in any event. $^{127}$ There thus still seems to be a need in South African law to find suitable alternative debt relief measures that also provide for a discharge outside the ambit of insolvency law under certain circumstances. ${ }^{128}$ The notion of assetless estates must also be addressed within the ambit of such reform initiatives. $^{129}$

125 See for instance $R$ v Meer 1957 (3) SA 614 (N) 619 and Ex Parte Pillay; Mayet $v$ Pillay 1955 (2) SA 309 (N) 311E and the recent Ex parte Ford 2009 (3) SA 376 (WCC) par 21.

126 See the Insol International: Consumer Debt Report (2001) referred to by Boraine (n 42) 238; and Calitz 2007 Obiter 397 regarding the latest trends and law reform in the United States.

127 See ch 13 of the US Bankruptcy Code of 1978 (as amended); Boraine (n 42) 235; Bertelsmann et al (n 108) 4; and Calitz (n 127) 397.

128 See for instance Boraine and Roestoff 1993 De Jure 229; Boraine and Roestoff 1994 De Jure 31; Boraine and Roestoff 2002 INSOL 1; Boraine (n 42) 217; Evans (n 64) 485; and Bertelsmann et al (n 108) 1-5.

129 See Roestoff and Renke 2005 Obiter 561; and Roestoff and Renke 2006 Obiter 98 where a case is also argued regarding the possible use of the NINA principles regarding the treatment of assetless estates in England and Wales. 
It must nevertheless be conceded that the NCA is a laudable attempt by the legislature to address over-indebtedness by firstly trying to prevent it, or where it does occur by providing some further mechanisms - albeit not sufficient in all respects - to address the situation. ${ }^{130}$ The plight of debtors who are too poor to go bankrupt and who cannot succeed in obtaining an alternative debt relief measure like that in Van Rooyen $v$ Van Rooyen ${ }^{131}$ has not been addressed adequately by the NCA - despite its noble aims. ${ }^{132}$

\subsection{Compulsory sequestration}

In view of the Ford decision it is now clearly a question if the same considerations will apply in the case of compulsory sequestration where the debt is substantially credit agreement debt. It is submitted that a court will be at liberty to pose the same questions when exercising its discretion whether to grant the application or not. The fact, however, that a creditor brings the application may be a factor that may influence the court to exercise its discretion in favour of granting the order; that is, if all the requirements for such an order are met. If the application is viewed as a so-called friendly sequestration, the court may adhere more strictly to the Ford approach, since friendly sequestration is often frowned upon by the courts.

\subsection{Sequestration subsequent to restructuring or debt rearrangement}

In Ford the granting of a sequestration order was considered at a time when the debtors had not yet considered debt review as an option. It may of course happen that a debtor defaults on a debt restructuring following debt review. In such an instance a credit provider can proceed with individual litigation as the section 88(3) bar is lifted. Obviously, if grounds for compulsory sequestration

130 Bertelsmann et al (n 108) 5.

131 Van Rooyen $v$ Van Rooyen (Automutual Investments (EC) (Pty) Ltd, Intervening Creditor) [2000] 2 All SA 485 (SE).

132 See Evans (n 64) 485 for a discussion of this case and sources referred to in n 121 and 122 above. 
exist and the credit provider opts for that route, the debtor's inability to comply with the restructuring or rearrangement order may be a factor pointing towards sequestration as the better option in terms of the advantage of creditors' requirement.

\section{Conclusion}

With reference to the questions posed in the introduction to this article, ${ }^{133}$ it may firstly be stated that the NCA does not specifically exclude the application of the Insolvency Act. ${ }^{134}$ At the same time it is important to note that the NCA applies to credit agreements regulated by it and contains certain debt relief measures for over-indebted consumer-debtors relating to such debt only. ${ }^{135}$ It is nevertheless submitted that the NCA will significantly influence insolvency proceedings, for instance, as a result of the powers of a court in terms of section 85 to refer the matter to debt review and thereby to invoke the debt relief remedies afforded by the NCA in respect of over-indebtedness. As a result of such a referral the remedies in respect of reckless credit as set out in section 83 may also come into play. As such it may happen in specific cases that a court may within the broader context of advantage to creditors, in its discretion to grant or refuse a sequestration order exercise the 'sub-discretion' to order that a consumer who has not yet been for debt review should do so in order for the court to make an informed decision on the advantage requirement, or that a debt restructuring order be maintained as it appears to be more advantageous than sequestration. Where a creditor who does not have a credit agreement claim thus decides to sequestrate a consumer who has other debts that constitute credit agreements for purposes of the NCA, he might find his application thwarted by an intervening creditor who alleges that debt restructuring is the better option. 
Secondly, it is submitted that the provisions of section 88(3) of the NCA apply only to credit providers who want to exercise and enforce their rights under a credit agreement by means of litigation or a judicial process and not to any other creditors. ${ }^{136}$ To this extent it has been argued that a credit provider may also bring an application for compulsory sequestration against a consumerdebtor. Clearly such an applicant will have to meet the requirements set for such an application and convince the court that there is sufficient reason to grant a sequestration order in spite of a debt rearrangement.

Thirdly, within its discretion to grant a sequestration order that is either based upon compulsory sequestration or voluntary surrender, a court may consider alternative options such as the debt review provided for by the NCA before granting such a sequestration order. If the Ford-judgement is anything to go by it is submitted that, especially in applications for voluntary surrender, applicantdebtors will have to consider their options outside sequestration - especially the debt relief procedures provided for by the NCA - before making application. $^{137}$

Essentially it appears that the NCA has at least indirectly introduced a consideration of the possible advantages that may be yielded by the debt relief remedies in respect of over-indebtedness and reckless credit as yet another factor to be taken into account by a court when considering advantage to creditors as an integral part of exercising its discretion in insolvency proceedings. In order to prevent a waste of costs and time, a consumer who wishes to apply for voluntary surrender of his estate would therefore be well advised to consider going for debt review first and making sure that the debt counsellor also investigates the possibility of reckless credit. A credit provider who wishes to apply for sequestration knowing that a consumer is under debt 
review or debt restructuring might also save himself unnecessary costs and delay by setting out sufficient detail to convince the court that sequestration is the most advantageous option. One would nevertheless hope that courts when exercising their discretions in sequestration applications will follow a commonsense approach by considering the best possible solution in every instance. ${ }^{138}$ For instance, it does not appear from the Ford-case judgement that any of the creditors actually opposed the application. One wants to assume that the creditors involved in this case had weighed their options to collect the debt in other ways before deciding not to oppose the matter.

There might also be a clash of interests where the debt situation of a particular consumer debtor consists of credit agreements as well as of other types of debt that are not regulated by the NCA, or where all of the debt amounts to credit agreements but with different credit providers. In the first instance a credit provider may for instance enjoy the benefit of a mere rescheduling of the repayment of his debt following debt review, whilst the other creditor is unable to obtain payment. The credit provider may also be privy to more financial information regarding the consumer debtor, whilst the other creditor may want to use compulsory sequestration as a way of gathering information regarding the debtor and the fate of his assets.

Although it must be conceded that the NCA will address the problem of overindebtedness to some extent - for instance by the reckless granting of credit, thus prompting credit providers to be more careful before making credit available to consumers who cannot afford it - the problem of over-indebtedness will remain, since many consumers who may have been credit-worthy at the time of obtaining credit will be influenced by economic realities that will impair their ability to repay such debt. It is clear that the purpose of the NCA is not to

138 Although in a different context, the court in Standard Bank of South Africa Ltd v Hales as discussed in par 2.1.1 above followed a commonsense approach by looking into the feasibility of referring a matter to a debt counsellor for a recommendation, where chances seemed to be slim that debt re-arrangement would rescue the debt situation of the consumer in any meaningful way. 
offer comprehensive relief to over-indebted debtors but merely to offer limited relief to some consumers who are subject to this Act. In fact, this type of relief will be effective only where a consumer still has the means or the potential to repay his debt in full if one of the prescribed relief options is granted to him in terms of the NCA.

At present the only real statutory discharge offered to debtors remains the rehabilitation that follows sequestration, and it remains largely a policy consideration if our legal system should also offer a discharge to some overindebted debtors outside of this ambit. It is nevertheless submitted that the full spectrum of debt relief measures still needs further research with the view of establishing proper mechanisms with a clear application in order to deal with the variety of debt situations that may arise. This is especially needed since the debt relief measures of the NCA deal only with credit agreements in terms of the Act, and such measures do not provide for a time-limitation for repayment or a statutory discharge.

The irony is that despite the NCA's apparent aim to assist over-indebted consumers it often perpetuates their debt trap by failing to provide a debt discharge, as opposed to the Insolvency Act which, despite its apparent attempt to collectively further the advantage of creditors, also indirectly serves the interests of debtors by providing for a debt discharge, and gives meaning to the word 'rehabilitation' by providing the possibility of a fresh start for overburdened consumers. It is submitted that only a proper empirical study will provide answers as to the efficacy of the new debt relief measures introduced by the NCA, and as to if they can really replace sequestration as an effective alternative. The same problems encountered for instance by administration orders in terms of section 74 of the Magistrates' Courts Act of 1944, that in many instances the extended repayment periods tend to increase the overindebtedness of many debtors rather than improve the situation, may also occur within the ambit of the new debt relief measure. If a holistic approach were followed, the role of debt counsellors could, for instance, have been 
extended to their assisting over-indebted consumers with all of their debts and directing them towards the most effective debt relief device for each one's unique debt situation.

Finally, it is clear that insolvency practitioners will have to take note of the possible impact of the NCA on insolvency law in general, and to make the required adjustments. It nevertheless remains a pity that the legislature did not reform the full spectrum of debt relief measures and also simultaneously align it with the Insolvency Act. This is pertinently problematic since the NCA does not regulate all types of debt, and the interests of such creditors may clearly come into conflict with the interests of credit providers whose debt has been rearranged in terms of the Act. 


\section{Bibliography}

Bertelsmann et al Mars

Bertelsmann et al Mars: The Law of Insolvency in South Africa (2008)

Boraine 2003 De Jure

Boraine A "Some thoughts on the reform of administration orders and related issues" 2003 De Jure 217-251

Boraine and Roestoff 1993 De Jure

Boraine A and Roestoff M "Vriendskaplike Sekwestrasies: 'n Produk van Verouderde Regsbeginsels? (Part 1)" 1993 De Jure 229-236

Boraine and Roestoff 1994 De Jure

Boraine A and Roestoff M "Vriendskaplike Sekwestrasies: 'n Produk van Verouderde Regsbeginsels? (Part 2)" 1994 De Jure 31-53

Boraine and Roestoff 2002 INSOL

Boraine $A$ and Roestoff $M$ "Fresh Start Procedures for Consumer Debtors in South African Bankruptcy Law" 2002 International Insolvency Review 111

Calitz 2007 Obiter

Calitz J "Developments in the United States' Consumer Bankruptcy Law: A South African Perspective" 2007 Obiter 397-417

Evans 2001 SA Merc LJ

Evans R "Friendly sequestrations, the abuse of the process of court" 2001 SA Mercantile Law Journal 485-508

Greig 2000 SALJ

Greig MA "Administration orders as shark nets" 2000 South African Law Journal 622-626

Nagel et al Commercial Law

Nagel CJ Commercial Law (LexisNexis Butterworth Durban 2006) 60/161 
Otto National Credit Act explained

Otto JM The National Credit Act explained (LexisNexis Butterworth Durban 2006)

Roestoff and Renke 2005 Obiter

Roestoff $\mathrm{M}$ and Renke S "Debt Relief for Consumers - The interaction between Insolvency and Consumer Protection Legislation (Part 1)" 2005 Obiter 561-574

Roestoff and Renke 2006 Obiter

Roestoff M and Renke S "Debt Relief for Consumers - The interaction between Insolvency and Consumer Protection Legislation (Part 2)" 2006 Obiter 98-110

Scholtz et al Guide to the National Credit Act

Scholtz JW et al Guide to the National Credit Act (LexisNexis Butterworth Durban 2008)

Sharrock et al Hockly's Insolvency Law

Sharrock R et al Hockly's Insolvency Law (Juta Cape Town 2007)

Stoop 2008 De Jure

Stoop PN "Kritiese evaluasie van die toepassingsveld van die 'National

Credit Act"' 2008 De Jure 332-351

Van Heerden 2008 JSAL

Van Heerden CM "Perspectives on jurisdiction in terms of the National

Credit Act 34 of 2005" 2008 Journal of South African Law 840-855

\section{Register of legislation and policy documents}

Credit Agreements Act 75 of 1980

Insolvency Act 24 of 1936

Integration of Usury Laws Act 57 of 1996

Magistrates' Courts Act 32 of 1944 
National Credit Act 34 of 2005

Usury Act 73 of 1968

\section{Register of court cases}

BP Southern Africa (Pty) Ltd v Furstenburg 1966 (1) SA 717 (O)

Braithwaite v Gilbert 1984 (4) SA 717 (W)

Commissioner, South African Revenue Services v Hawker Air Services (Pty)

Ltd; Commissioner, South African Revenue Services v Hawker Aviation

Partnership 2006 (4) SA 292 (SCA)

De Villiers NO v Maursen Properties (Pty) Ltd 1983 (4) SA 670 (T)

DP Du Plessis Prokureurs v Van Aarde 1999 (4) SA 1333 (T)

Dunlop Tyres (Pty) v Brewitt 1999 (2) SA 580 (W)

Ex Parte B Z Stegmann 1902 TS 40

Ex parte Ford 2009 (3) SA 376 (WCC)

Ex parte Ford [2009] JOL 23412 (WCC)

Ex parte Harmse 2005 (1) SA 323 (N) 325

Ex parte Hayes 1970 (4) SA (NC) 96C

Ex parte Pillay; Mayet v Pillay 1955 (2) SA 309 (N)

Ex parte Steenkamp and related cases 1996 (3) SA 822 (W)

Fesi v ABSA Bank Ltd 2000 (1) SA 499 (C)

Firstrand Bank Ltd v Olivier 2009 (3) SA 353 (SE)

Julie Whyte Dresses (Pty) Ltd v Whitehead 1970 (3) SA 218 (D)

London Estates (Pty) Ltd v Nair 1957 (3) SA 591 (D)

Lynn \& Main Inc v Naidoo 2006 (1) SA 59 (N)

Meskin \& Co v Friedman 1948 (2) SA 555 (W)

Nel NO $v$ Body Corporate of the Seaways Building 1996 (1) SA 131 (SCA)

$R v$ Meer 1957 (3) SA $614(\mathrm{~N})$

Richter NO v Riverride Estates (Pty) Ltd 1946 OPD 209

Samsudin v De Villiers Berrange NO [2006] SCA 79 (RSA)

Standard Bank of South Africa Ltd v Hales 2009 (3) SA 315 (D)

Standard Bank of South Africa Ltd v Panayiotts 2009 (3) SA 363 (W)

Trust Wholesalers and Woollens (Pty) Ltd v Mackan 1954 (2) SA 109 (N) 
Van Rooyen v Van Rooyen (Automutual Investments (EC) (Pty) Ltd, Intervening Creditor) [2000] 2 All SA 485 (SE)

Venter v Volkskas Ltd 1973 (3) SA 175 (T) 179

Volkskas Bank ('n Divisie van Absa Bank Beperk) v Pietersen 1993 (1) SA 312

(C)

Walker v Syfret NO 1911 AD 141166

Walker v Walker [1998] 2 All SA 382 (W)

WP Kooperatief Bpk v Louw 1995 (4) SA 4 (O)

\section{List of abbreviations}

ch chapter(s)

NCA National Credit Act

par paragraph(s)

reg regulation(s)

s section(s) 